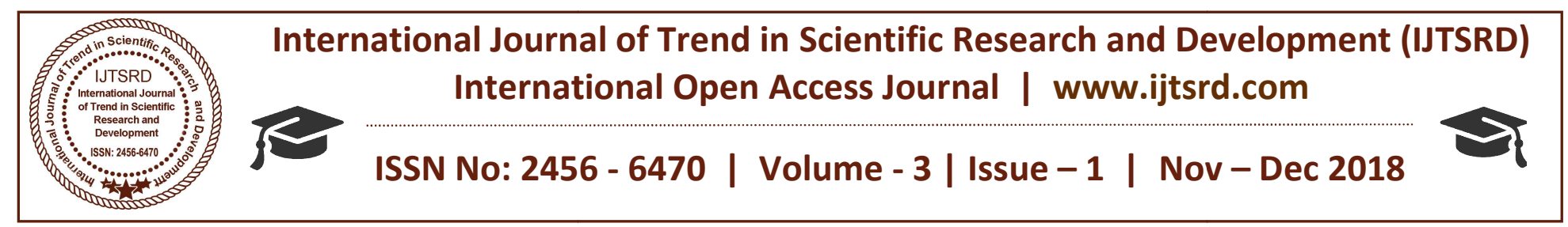

\title{
Role of Oxidative Stress in Assessment of Damage Induced by Lead Acetate in Mice Gastrocnemius Muscle
}

\author{
Sushma Sharma ${ }^{1}$, Anita Thakur ${ }^{2}$ \\ ${ }^{1}$ Professor, ${ }^{2} \mathrm{PhD}$ Scholar \\ Department of Biosciences, Himachal Pradesh University, Summer Hill, Shimla, India
}

\begin{abstract}
Heavy metal deposition has increased due to the anthropogenic activities leading to heavily polluted areas worldwide. The objective of present study was to evaluate the effect of lead acetate $[\mathrm{Pb}(\mathrm{C} 2 \mathrm{H} 3 \mathrm{O} 2) 2]$ on antioxidant enzyme activities in gastrocnemius muscle of mice. Lead is a toxic heavy metal widely distributed in the environment due to its role in modern industry. Normal healthy looking mice showing no sign of morbidity were divided into three groups. Group I was designated as control whereas group II and group III received lead acetate having doses $10 \mathrm{mg} / \mathrm{kg}$ body weight of lead acetate, daily and $150 \mathrm{mg} / \mathrm{kg}$ body weight of lead acetate, weekly respectively. Study was performed at 40 and 80 days stages. Lead acetate significantly decreases antioxidant enzymes and increase oxidative stress along with muscle tissue damage.
\end{abstract}

KEY WORDS: Lead acetate, gastrocnemius muscle, Antioxidant enzymes

\section{INTRODUCTION}

There are 35 metals that are of concern for us because of residential and occupational exposure. These heavy metals are commonly found in the environment and diet. In small amount they are required for maintaining good health but in large amount they can become toxic or dangerous. Increase in blood lead concentration also affects a person IQ (Taylor et al, 2012). Exposure to the heavy metals mainly lead occurs from automobile exhaust in those areas where leaded gasoline is still used and also from the drinking water in those regions where lead pipes are being used. Of all heavy metal that contaminate the environment and pose hazards to public health lead has been of major concern. Along with environmental pollutant, lead is a metabolic poison with a variety of toxic effects.

Recent studies proposed that one possible mechanism of lead toxicity is the disturbance of pre-oxidant and antioxidant balance by generation of reactive oxygen species (ROS) (Gurer and Ercal, 2000; Wang et al., 2000). At very high concentration reactive oxygen species may causes structural damage to cells, proteins, nucleic acid and lipids resulting in a stressed situation at cellular level (Mathew et al., 2011). It has been also reported that lead exposure has a dose dependant response relationship with changes in antioxidant enzyme levels and their activities (Adonaylo and Oteiza, 1999). The ionic mechanism of lead toxicity occurs mainly due to the ability of lead metal ions to replace other bivalent cations like $\mathrm{Ca} 2+, \mathrm{Mg} 2+, \mathrm{Fe} 2+$ and monovalent cations like $\mathrm{Na}+$, which ultimately disturbs the biological metabolism of the cell (Flora et al, 2012).

Lead acetate generation of free radicals may attack not only DNA of the cell, but also the polyunsaturated fatty acid residues of phospholipids in other organelles that are sensitive to oxidation (Sharma et al., 2010). The generation of reactive oxygen species such as superoxide ion, hydrogen peroxide and hydroxyl radicals (Hermes-Lima et al., 1991; Stohs and Bagchi, 1995) have been implicated in lead toxicity (Adonaylo and Oteiza, 1999). The antioxidant enzymes superoxide dismutase (SOD) and catalase (CAT) are potential targets of lead.

Materials and methods: All the experimental procedure was conducted after the approval of Institutional Animal Ethics Committee (IAEC/Bio/62011) of Himachal Pradesh University, Shimla, India. 
Present study was conducted on gastrocnemius muscle of adult sexually mature Swiss albino mice weighing $20-30 \mathrm{~g}$. They were maintained in polypropylene cages under hygienic conditions. Animals were allowed to acclimatize to the laboratory conditions for 10 days. They were fed upon Hindustan lever pellets diet and water ad libitum.

Chemicals: All reagents used were of highest grade. Lead acetate used for this study was obtained from Sigma Chemicals, St. Louis, MO, USA.

\section{Grouping of animals and dose administration:}

Normal healthy looking mice showing no sign of morbidity were divided into three groups:-

$>$ Group I served as control

$>$ Group II received oral administration of lead acetate $(10 \mathrm{mg} / \mathrm{kg}$ body weight $)$ daily

$>$ Group III administered lead acetate $(150 \mathrm{mg} / \mathrm{kg}$ body weight), weekly

Lead acetate was given for 40 days and mice were sacrificed at 1, 40 and 80 days period by cervical dislocation.

\section{Biochemical studies:}

Total protein was measured as per the method of Lowry et al., (1951). Superoxide dismutase was done as per the method of Mishra and Fridovich (1972) and catalase activity was determined by monitoring the decomposition of hydrogen peroxide by measuring the changes in absorbance at $240 \mathrm{~nm}$. The enzyme activity was calculated in units' $\mathrm{mg}^{-1}$ protein.

Results: The present study confirmed that exposure to lead acetate produced significant alterations in antioxidant enzyme activities i.e. Superoxide dismutase (SOD) and catalase (CAT). In gastrocnemius muscle, at day 1, after administration of lead acetate, the SOD and CAT activity showed a progressive increase which was due to increased oxidative stress. However at 40 days stage, significant decrease was seen in antioxidant levels after lead acetate treatment. Again at 80 days stage enzyme activity was found to be low when compared with normal ones, although percentage decline was less than that of 40 days stage.

Table and Fig. I: Change in superoxide dismutase specific activity (units/mg protein) in gastrocnemius muscle of normal and lead acetate treated mice 1-80 days period. Values are mean \pm SEM; $n=3\left(P^{*}<\right.$ 0.05)

Table I

\begin{tabular}{|c|c|c|c|}
\hline \multirow{2}{*}{ Groups } & \multicolumn{3}{|c|}{ Days } \\
\hline & 1 & 40 & 80 \\
\hline $\mathrm{ON}$ & $8.97 \pm 0.016$ & $9.31 \pm 0.024$ & $9.61 \pm 0.013$ \\
\hline Lead acetate (10 mg/kg body weight) & $9.23 \pm 0.012$ & $8.07 \pm 0.018$ & $8.37 \pm 0.007^{*}$ \\
\hline$\%$ increase or decrease & $2.89 \%$ & $-13.31 \%$ & $-12.90 \%$ \\
\hline Lead acetate (150 mg/kg body weight) & $10.32 \pm 0.017$ & $7.69 \pm 0.007^{*}$ & $8.03 \pm 0.003$ \\
\hline$\%$ increase or decrease & $15.05 \%$ & $-17.40 \%$ & $-16.44 \%$ \\
\hline
\end{tabular}

Fig. I

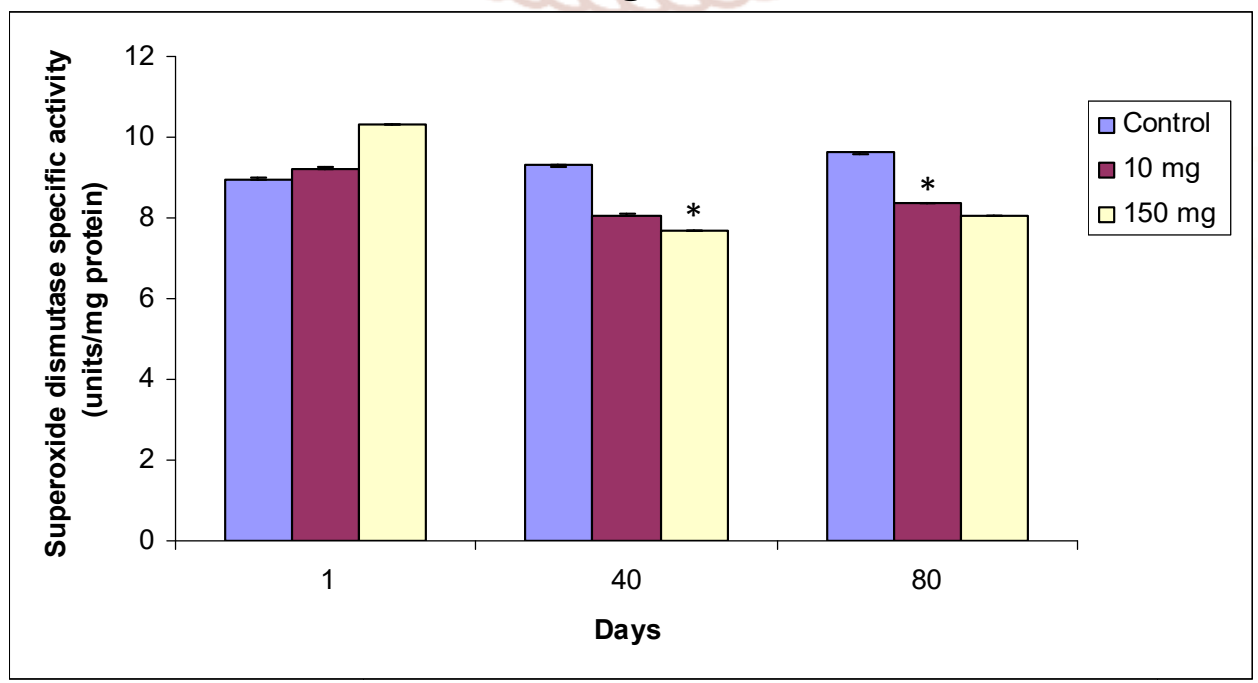


Table \& Fig. II:Changes in catalase specific activity (units/mg protein) in gastrocnemius muscle of normal and lead acetate treated mice during 1-80 days period. Values are mean $\pm S E M ; n=3(P *<0.05)$

Table II

\begin{tabular}{|l|l|l|l|}
\hline \multirow{2}{*}{ Groups } & \multicolumn{3}{|c|}{ Days } \\
\cline { 2 - 4 } & \multicolumn{1}{|c|}{1} & \multicolumn{1}{c|}{40} & \multicolumn{1}{c|}{80} \\
\hline Control & $9.14 \pm 0.074$ & $9.65 \pm 0.066$ & $9.83 \pm 0.019$ \\
\hline Lead acetate (10 mg/kg body weight) & $10.50 \pm 0.146$ & $8.16 \pm 0.027 *$ & $8.83 \pm 0.085$ \\
\hline \% increase or decrease & $14.87 \%$ & $-15.44 \%$ & $-11.07 \%$ \\
\hline Lead acetate (150 mg/kg body weight) & $11.85 \pm 0.154 *$ & $7.48 \pm 0.044$ & $8.37 \pm 0.147$ \\
\hline \% increase or decrease & $29.64 \%$ & $-22.48 \%$ & $-15.19 \%$ \\
\hline
\end{tabular}

Fig. II

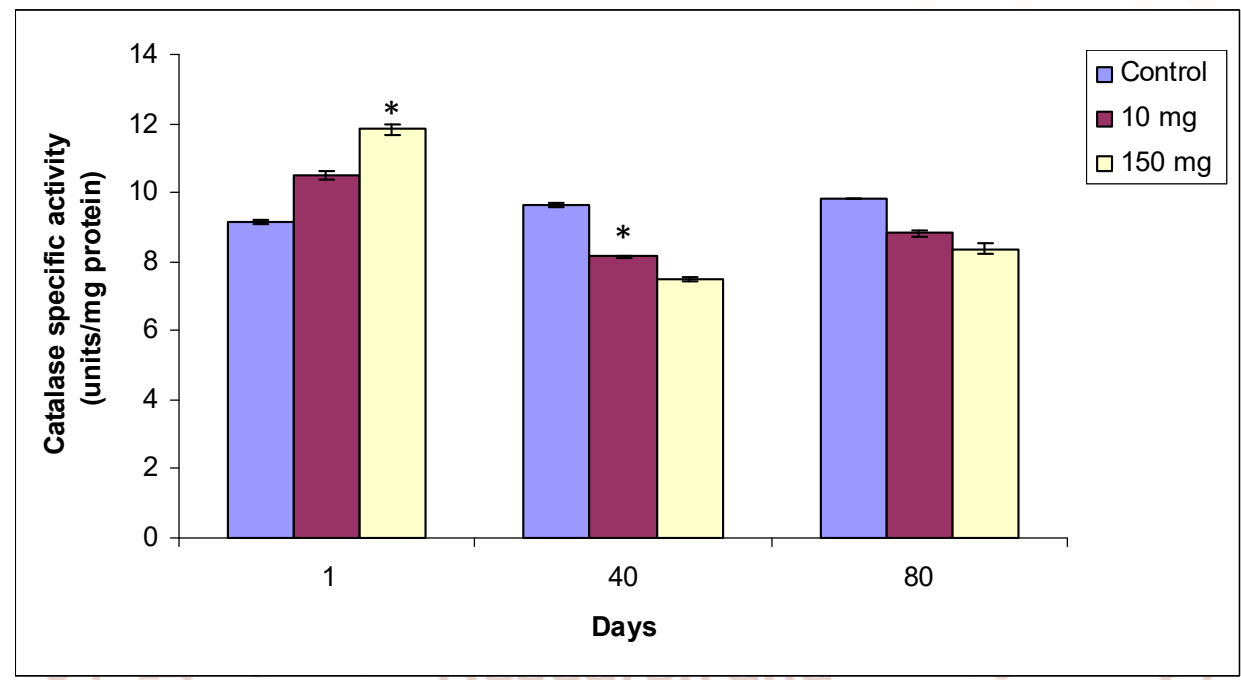

\section{Discussion:}

Skeletal muscle is a highly specialized tissue with excellent plasticity in response to external stimuli. High muscle activity also involves a strong increase in reactive oxygen species. Simultaneously body's antioxidant defense system is able to neutralize free radicals by accepting the unpaired electron and thereby inhibit oxidation of other molecules. Lead is highly toxic metal whose widespread use has caused extensive environmental contamination and other health issues. Lead metal causes toxicity in living cells by following ionic mechanism and that of oxidative stress. Antioxidants, present in the cell protect it from free radicals, however under the influence of lead the level of reactive oxygen species increases and the level of antioxidant decreases (Jaishankar, M. et al., 2014). The antioxidant enzymes superoxide dismutase (SOD) and catalase (CAT) are primary defense against reactive oxygen species generated during exercise and increase in response to exercise (Ji, 1995; Sen, 199).

The objective of this study was to see the effect of lead acetate on antioxidant enzymes. Experimental finding of present investigation explains the ability of lead acetate to cause disturbances in normal functioning of muscles. The antioxidant enzyme level in control group remains fairly constant throughout the experimental time period. After 24 hours of exposure it exhibited a significant increase when compared with control. SOD and CAT activities were decreased after 40 days treatment of lead acetate. However at 80 days stage, after the withdrawal of lead acetate at 40 days stage decline in antioxidant enzymes was less than the control mice at 80 days stage.

The overproduction of reactive oxygen species such as hydrogen peroxide $\left(\mathrm{H}_{2} \mathrm{O}_{2}\right)$, superoxide anion $\left(\mathrm{O}_{2}\right)$ and hydroxyl radical $(\mathrm{OH})$ in the tissue of organisms causes oxidative damage in organism (Bhanu, 2016). As in present study lead acetate is found to cause oxidative stress in muscle as the antioxidant system has been estimated to increase the production of various defensive enzymes. Our findings were in accordance with those from previous studies. Aina et al, (2012) who have shown that the oxidative stress 
would increase the level of defensive enzymes under the toxicity of pollutants. Saliu and Bawa Allah (2012) have found that the increased quantity of antioxidant enzymes would help the organisms to overcome the oxidative stress by regulative bioaccumulation of the metals to levels the body can tolerate. According to Begum and Sengupta (2014) increased activity level of antioxidant enzyme indicate the adaptational and protective response of animals under pollutant toxicity.

\section{Conclusion:}

Data from present study suggest that entire antioxidant system is stimulated to start increased production of antioxidant enzymes to detoxify the free radicals and to remove from the cells to overcome the oxidative stress caused by lead acetate.

\section{References:}

1. Adonaylo, V. N. and Oteiza, P. I. (1999). Lead intoxication: antioxidant defenses and oxidative damage in rat brain. Toxicol., 135: 77-85.

2. Aina, O., Adeogun, Ilelabayo, M., Ogidan, Oju. R., Ibor, Azubuike, V., Chukwuka, Issac. A., Ajedara, Ebenezer, O. (2012). Long term exposure to industrial effluent induces oxidative stress and affects growth in Clarias gariepinus, Res J of env and earth sci, 4(7), pp $738-746$.

3. Begum, M. and Sengupta, M. (2014). Effects of mercury on the activities of antioxidant defences in intestinal macrophages of fresh water teleost Channa punctatus. IJFAS, 2(1): 172-179.

4. Bhanu, A. P. (2016). Studies on the influence of heavy metals on antioxidant system in the tissues of fresh water fish Cyprinus carpio. IJREAS 6(5): 11-14.

5. Flora, S.J.S., Mittal, M., Mehta, A. (2012). Heavy metal induced oxidative stress \& its possible reversal by chelation therapy. Indian $J$ Med Res 128: $501-523$.

6. Gurer H., Ercal N. (2000). Can antioxidants be beneficial in the treatment of lead poisoning? Free Radic Biol Med, 29:927-945.

7. Hermes - Lima, M., Pereira, B. and Bechara, E. J. (1991). Are free radicals involved in lead posoinging? Xenobiotica. 21: 1085-1090.
8. Jaishankar, M., Tseten, T., Anbalagan, N., Mathew, B. B., Beeregowda, K. N. (2014). Toxicity, mechanism and health effects of some heavy metals. Toxicol., 7(2): 60-72.

9. Ji, L.L. (1995). Exercise and oxidative stress: Role of cellular antioxidant systems. Exerc Sport Sci Res., 23:135-166.

10. Lowry, O. H., Rosenbrough, N.J., Farr, A.L. and Randall, R.J. (1951). Protein measurements with the Folin - phenol reagent. J Biol Chem., 193: 265-275.

11. Mathew, B.B., Tiwari, A., Jatawa, S.K. (2011). Free radicals and antioxidants: A review. $\mathrm{J}$ of Pharm Res 4(12):4340-4343.

12. Mishra, H.P. and Fridovich, I. (1972). The role of superoxide anion in the auto - oxidation of epinephrine and a simple assay for superoxide dismutase. J Biol Chem., 247: 3170 - 3175.

13. Saliu, J. K. and Bawa - Allah, K. A. (2012). Toxicological effects of lead and zinc on the antioxidant enzyme activities of post juvenile Clarias gariepinus. Resour Environ, 2, pp $21-26$.

14. Sen, C. K. (1995). Oxidants and antioxidants in exercise. J Appl Physiol., 79: 675-686.

15. Sharma, V., Sharma, A. and Kansal, L. (2010). The effect of oral administration of Allium sativum extracts on lead acetate induced toxicity in male mice. Food Chem. Toxicol., 48: 928-936.

16. Stohs, S. J. and Bagchi, D. (1995). Oxidative mechanisms in the toxicity of metal ions. Free Radical Biol Med., 18(2): 321-336.

17. Taylor, M. P., Winder, C., Lanphear, B. P. (2012). Eliminating childhood lead toxicity in Australia: a call to lower the intervention level. MJA 197 (9): 493.

18. Wang H., P., Qian S., Y., Schafer F., Q., Domann F., E., Oberley L., W., Buettner G., R. (2000). Phospholipid hydroperoxide glutathione peroxidase protects against singlet oxygen induced cell damage of photodynamic therapy. Free Radic Biol Med, 30:825-835. 